\title{
Synthesis and Characterization of New Optically Active Poly (ethyl L-lysinamide)s and Poly (ethyl L-lysinimide)s
}

\author{
Saeed Zahmatkesh ${ }^{1}$ and Mohammad Reza Vakili \\ ${ }^{1}$ Department of Science, Payame Noor University (PNU), Tehran 19569, Iran \\ ${ }^{2}$ Department of Chemistry, Islamic Azad University, Firouzabad, 74715-117 Fars, Iran \\ Correspondence should be addressed to Saeed Zahmatkesh, zahmatkesh1355@yahoo.com
}

Received 21 February 2010; Revised 27 April 2010; Accepted 15 June 2010

Academic Editor: Norbert Sewald

Copyright ( 2010 S. Zahmatkesh and M. R. Vakili. This is an open access article distributed under the Creative Commons Attribution License, which permits unrestricted use, distribution, and reproduction in any medium, provided the original work is properly cited.

\begin{abstract}
Ethyl L-lysine dihydrochloride was reacted with three different dianhydrides to yield the poly (ethyl L-lysinimide)s $\left(\mathbf{P I}_{\mathbf{1 - 3}}\right)$; it was also reacted with two different diacyl chlorides to yield the poly (ethyl L-lysinamide)s $\left(\mathbf{P A}_{\mathbf{4}-5}\right)$. The resulting polymers have inherent viscosities in the range of 0.15 to $0.42 \mathrm{dL} \mathrm{g}^{-1}$. These polymers are prepared from an inexpensive starting material and are optically active, potentially ion exchangeable, semicrystalline, thermally stable, and soluble in polar aprotic solvents such as DMF, DMSO, NMP, DMAc, and sulfuric acid. All of the above polymers were fully characterized by FT-IR and ${ }^{1} \mathrm{H}$ NMR spectroscopy, elemental analysis, WAX diffraction, TGA, inherent viscosity measurement, and specific rotation.
\end{abstract}

\section{Introduction}

Polyamides, Polyimides, and their copolymers are certainly one of the most useful classes of high-performance polymers, which have found many applications in industries as discussed by Mittal [1] and Abade [2]. Aromatic polyimides are an important class of heterocyclic polymers with remarkable heat resistance and superior mechanical and electrical properties, and also durability as discussed by Banihashemi and Abdolmaleki [3], Ghosh and Mittal [4] and Wilson et al. [5]. Various efforts have been focused on the preparation of soluble and/or thermoplastic polyimides, while still maintaining the excellent thermal and mechanical properties. Typical approaches that have been employed to improve the processability of them include the incorporation of flexible links as discussed by Tamai et al. [6], bulky pendant or cardo groups as discussed by Hsiao and Li [7] and Müller and Ringsdorf [8], kinked or asymmetric structures as discussed by Li et al. [9], and spiro skeletons as discussed by Reddy et al. [10] into the polymer chain. These modifications lower the melting temperature and lead to soluble and amorphous polymers. In general, amorphous polymers have a lower softening temperature $(\mathrm{Tg})$ and improved solubility with respect to their crystalline analogues. Some of the block copolymers composed of polyethers and polyamides have already been commercialized as thermoplastic elastomers as discussed by Legge et al. [11]. A number of synthetic routes for polyether-polyimide block copolymers have been known as discussed by Noshay and McGrath [12]. The synthesis and application of optically active polymers is a considerable topic, which has been paid more attention recently as discussed by Hajipour et al. [13]. Most of the natural polymers are optically active and have special chemical activities, such as catalytic properties that exist in genes, proteins, and enzymes. Some other applications are construction of chiral media for asymmetric synthesis, chiral stationary phases for resolution of enantiomers in chromatographic techniques as discussed by Akelah and Sherrington [14], Aglietto et al. [15], Yuki et al. [16], Okamoto and Yashima [17], and Soai and Niwa [18], chiral liquid crystals in ferroelectrics and nonlinear optical devices as discussed by Wulff [19] and Fontanille and Guyot [20]. These synthetic polymers based on optically pure amino acids can induce crystallinity with their ability to form higher ordered structures that exhibit enhanced solubility characteristics as discussed by Birchall et al. [21]. These properties have caused them to be good candidate for drug delivery systems, biodegradable macromolecules, biomaterials, and also as chiral purification 
media as discussed by Mallakpour et al. [22]. So, more considerations to improve different synthetic procedures of optically active polymers exist. Recently, we have synthesized optically active polymers by different methods as discussed by Mallakpour et al. [23, 24] and Hajipour et al. [25]. L-lysine with good functionalities has been used to prepare some polytartaramides as discussed by Bou and Muñoz-Guerra [26] and Majó et al. [27]. In this research, we report the synthesis and characterization of some PAs and PIs from an inexpensive starting material through polycondensation in refluxing DMF. These polymers showed good optical activity $\left(-28.12^{\circ}\right.$ to $\left.-48.56^{\circ}\right)$ and because of the presence of pendent ester moiety they can potentially be ion exchangeable as discussed by Müller and Ringsdorf [8]. In $\mathbf{P I}_{2}$ because of the presence of benzophenone moiety, this polymer can potentially be photolabile. The photolabile polymers can potentially be used as affinity columns for protein purification as discussed by Guo et al. [28]. The outstanding characteristics of these polymers include thermal stability, good solubility, optical activity, semicrystallinity, potentially being photolabile and ion exchangeable.

\section{Material and Methods}

The dianhydrides (Merck) were recrystallized from acetic anhydride. The other chemicals (Merck) were used as received. ${ }^{1} \mathrm{H}$ NMR spectra were recorded on $300 \mathrm{MHz}$ (Bruker Avance) instrument, using DMSO- $\mathrm{d}_{6}$ as solvent and tetramethylsilane as shift reference (tube diameter, $5 \mathrm{~mm}$ ). IR spectra were recorded on a Shimadzu FT-IR-680 instrument, using $\mathrm{KBr}$ pellets. Specific rotations were measured by a JASCO P-1030 Polarimeter in DMF s solvent. UV spectra were recorded on a JASCO V-570 instrument in DMF solvent. Thermogravimetric analyses (TGA) were recorded on a Mettler TGA-50 with heating rate of $10^{\circ} \mathrm{C} \mathrm{min}-1$ under air atmosphere. Inherent viscosities of polymers were measured by a standard procedure using a KPG Cannon Fenske routine viscometer at $25^{\circ} \mathrm{C}$ using DMF as solvent. Melting points were measured in open capillaries with a Gallenkamp instrument. Elemental analyses were preformed in a Heraeus CHNS-RAPID instrument.

\subsection{Monomer Synthesis}

2.1.1. Synthesis of Ethyl L-Lysine Dihydrochloride (as discussed by Bou et al. [29]). In a $50 \mathrm{~mL}$ round-bottomed flask equipped with a reflux condenser and a stirring bar, $8 \mathrm{~mL}$ of thionyl chloride was added dropwise to the stirring absolute ethanol $(2.5 \mathrm{~mL})$ at $-10^{\circ} \mathrm{C}$. L-lysine hydrochloride $(7.3 \mathrm{~g}$, $0.04 \mathrm{~mol}$ ) was added to the mixture and refluxed for 6 hours. The solvent was evaporated under reduced pressure and the residue was washed with diethyl ether for three times. Yield: $87 \%$; m.p.: $136-137^{\circ} \mathrm{C}$; IR $\left(\mathrm{cm}^{-1}\right)$ : $3421,3350-$ 2514, 2019, 1740, 1603, 1583, 1501, 1217, 851, 740; ${ }^{1} \mathrm{H}-$ NMR ( $\left.\mathrm{D}_{2} \mathrm{O}, \mathrm{ppm}\right): 1.07(3 \mathrm{H}), 1.29(2 \mathrm{H}), 1.49(2 \mathrm{H}), 1.76$ $(2 \mathrm{H}), 2.78(2 \mathrm{H}), 3.91(1 \mathrm{H}), 4.08(2 \mathrm{H})$; Elemental analysis for $\mathrm{C}_{8} \mathrm{H}_{18} \mathrm{~N}_{2} \mathrm{O}_{2} \cdot 2 \mathrm{HCl}$, Calculated: $\mathrm{C}(38.87 \%), \mathrm{H}(8.16 \%)$, $\mathrm{N}(11.33 \%)$, Found: C (38.62\%), H (8.31\%), N (11.40\%).
2.1.2. Poly (ethyl L-lysinimide)s Synthesis, General Procedure. For the general procedure in a $25 \mathrm{~mL}$ round-bottomed flask equipped with a reflux condenser and a stirring bar, a mixture of dianhydride $(0.001 \mathrm{~mol})$, ethyl L-lysine dihydrochloride $(0.001 \mathrm{~mol}), \mathrm{Et}_{3} \mathrm{~N}(0.002 \mathrm{~mol})$, and DMF $(5 \mathrm{~mL})$ were placed. The mixture was stirred at r.t. for 2 hours and then at refluxing temperature for 5 hours. The mixture was poured dropwise into $15 \mathrm{~mL}$ of $\mathrm{H}_{2} \mathrm{O}$. The white precipitate was filtered off, washed with water, and dried under vacuum condition.

$\boldsymbol{P I}_{1} \quad$ (using pyromellitic dianhydride). Yield: 75\%; $\eta_{\text {inh }}^{\prime}$ $\left(\mathrm{dL} \mathrm{g}^{-1}\right)=0.42 ;[\alpha]_{D}^{25}=-30.68^{\circ} ; \mathrm{UV}\left(\lambda_{\max }\right): 263 ; \operatorname{IR}\left(\mathrm{cm}^{-1}\right)$ : 2980-2894, 2858, 1774-1680, 1495, 1458-1386, 1244, 1120, 1023, 719, 496; ${ }^{1} \mathrm{H}$ NMR (DMSO-d 6 , ppm): $1.26(2 \mathrm{H}), 1.41$ $(3 \mathrm{H}), 1.76-1.83(2 \mathrm{H}), 2.33(2 \mathrm{H}), 3.74(2 \mathrm{H}), 4.23(1 \mathrm{H}), 4.87$ $(2 \mathrm{H}), 8.06-8.29(2 \mathrm{H})$. Elemental analysis for $\mathrm{C}_{18} \mathrm{H}_{16} \mathrm{~N}_{2} \mathrm{O}_{5}$ : Calculated: C (63.52\%), H (4.73\%), N (8.23\%), Found: C $(63.42 \%), \mathrm{H}(4.80 \%), \mathrm{N}(8.11 \%)$. Wide-angle X-ray diffraction patterns of this polymer in the region of $2 \theta=$ $5-70^{\circ}$ at room temperature indicate $20-30 \%$ of crystallinity.

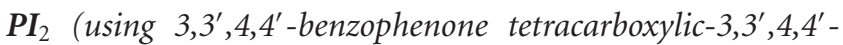
dianhydride). Yield: $80 \% ; \eta_{\text {inh }}^{\prime}\left(\mathrm{dL} \mathrm{g}^{-1}\right)=0.15 ;[\alpha]_{D}^{25}=$ $-48.56^{\circ}$; UV $\left(\lambda_{\max }\right): 265,290$; IR $\left(\mathrm{cm}^{-1}\right)$ : 2938, 1776$1715,1669,1619,1441,1385,1294,1246,1184,1157,1096$, 1024, 859, 726; ${ }^{1} \mathrm{H}$ NMR (DMSO-d 6 , ppm): $1.26(2 \mathrm{H}), 1.44$ $(3 \mathrm{H}), 1.75-1.82(2 \mathrm{H}), 2.34(2 \mathrm{H}), 3.73(2 \mathrm{H}), 4.24(1 \mathrm{H}), 4.87$ $(2 \mathrm{H}), 7.99-8.23(6 \mathrm{H})$. Elemental analysis for $\mathrm{C}_{25} \mathrm{H}_{20} \mathrm{~N}_{2} \mathrm{O}_{6}$ : Calculated: C (67.55\%), H (4.54\%), N (6.30\%), Found: C $(67.46 \%), \mathrm{H}(4.77 \%), \mathrm{N}(6.16 \%)$.

$\mathbf{P I}_{3}$ (using 4,4'-(hexaflouroisopropylidene) diphthalic anhydride). Yield: $70 \% ; \eta_{\text {inh }}^{\prime}\left(\mathrm{dL} \mathrm{g}^{-1}\right)=0.18 ;[\alpha]_{D}^{25}=-28.26^{\circ}$; UV $\left(\lambda_{\max }\right): 280$; IR $\left(\mathrm{cm}^{-1}\right): 2941,1779-1719,1442,1385$, 1297, 1255, 1210, 1140, 1105, 722; ${ }^{1} \mathrm{H}$ NMR (DMSO- $\mathrm{d}_{6}$, ppm): 1.05-1.12 (2H), $1.22(3 \mathrm{H}), 1.53-1.58(2 \mathrm{H}), 2.11(2 \mathrm{H})$, $3.49(2 \mathrm{H}), 4.01(1 \mathrm{H}), 4.65(2 \mathrm{H}), 7.60-7.99(6 \mathrm{H})$. Elemental analysis for $\mathrm{C}_{27} \mathrm{H}_{20} \mathrm{~N}_{2} \mathrm{O}_{5} \mathrm{~F}_{6}$ : Calculated: $\mathrm{C}(57.24 \%), \mathrm{H}$ (3.56\%), N (4.95\%), Found C (57.10\%), H (3.64\%), N $(4.86 \%)$.

2.1.3. Poly (ethyl L-lysinamide)s Synthesis, General Procedure. In a $25 \mathrm{~mL}$ round-bottomed flask equipped with a reflux condenser and a stirring bar, a mixture of aromatic acid dichloride $(0.001 \mathrm{~mol})$, ethyl L-lysine dihydrochloride $(0.001 \mathrm{~mol}), \mathrm{Et}_{3} \mathrm{~N}(0.004 \mathrm{~mol})$ and DMF $(5 \mathrm{~mL})$ were placed. The mixture was stirred at r.t. for 10 hours. The mixture was poured dropwise into $15 \mathrm{~mL}$ of $\mathrm{H}_{2} \mathrm{O}$. The white precipitate was filtered off, washed with water, and dried under vacuum conditions.

$\boldsymbol{P A}_{4}$ (using terephthaloyl dichloride). Yield: 65\%; $\eta_{\text {inh }}^{\prime}$ $\left(\mathrm{dL} \mathrm{g}^{-1}\right)=0.31 ;[\alpha]_{D}^{25}=-28.12^{\circ} ; \operatorname{UV}\left(\lambda_{\max }\right): 265 ; \operatorname{IR}\left(\mathrm{cm}^{-1}\right)$ : 3423, 2963, 1727-1615, 1505, 1439, 1410, 1276, 1197, 1118, 1018,$727 ;{ }^{1} \mathrm{H}$ NMR (DMSO-d 6 , ppm): $1.12(2 \mathrm{H}), 1.23-1.26$ $(3 \mathrm{H}), 1.32(2 \mathrm{H}), 1.38-1.60(2 \mathrm{H}), 1.82(2 \mathrm{H}), 2.96(2 \mathrm{H}), 3.29$ 


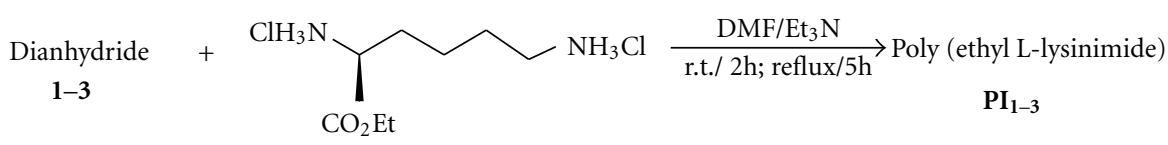<smiles>O=c1oc(=O)c2cc3c(=O)oc(=O)c3cc12</smiles>

1<smiles>O=C(c1ccc2c(c1)C(=O)OC2=O)c1ccc2c(c1)C(=O)OC2=O</smiles>

2<smiles>O=C1OC(=O)c2cc(C(c3ccc4c(c3)C(=O)OC4=O)(C(F)(F)F)C(F)(F)F)ccc21</smiles>

3

Head-to-tail regiorandomness of the polymer has not been represented for the sake of simplicity

Scheme 1: Poly (ester-imide) synthesis.

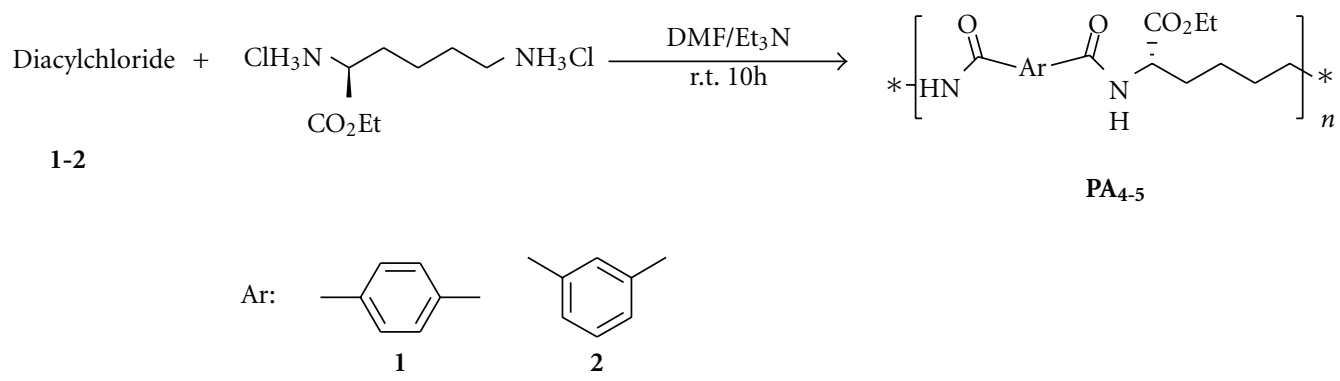

Head-to-tail regiorandomness of the polymer has not been represented for the sake of simplicity

Scheme 2: Poly (amide-imide) synthesis.

$(1 \mathrm{H}), 4.30(1 \mathrm{H}), 4.47(2 \mathrm{H}), 7.65-8.16(4 \mathrm{H}), 11.42(1 \mathrm{H})$. Elemental analysis for $\mathrm{C}_{16} \mathrm{H}_{20} \mathrm{~N}_{2} \mathrm{O}_{3}$ : Calculated $\mathrm{C}(66.65 \%)$, $\mathrm{H}(6.99 \%), \mathrm{N}(9.71 \%)$, Found C (66.54\%), H (7.07\%), N (9.66\%).

$\boldsymbol{P A}_{5}$ (using isophthaloyl dichloride). Yield: $60 \% ; \eta_{\text {inh }}^{\prime}\left(\mathrm{dL} \mathrm{g}^{-1}\right)$ $=0.17 ;[\alpha]_{D}^{25}=-30.22^{\circ} ; \mathrm{UV}\left(\lambda_{\max }\right): 265 ; \operatorname{IR}\left(\mathrm{cm}^{-1}\right): 3422$, 2962, 1722-1685, 1431, 1312, 1288, 1251, 1131-1077, 724;

${ }^{1} \mathrm{H}$ NMR (DMSO-d, ppm): $1.12(2 \mathrm{H}), 1.23-1.26(3 \mathrm{H}), 1.39$ (2H), 1.40-1.79 (2H), $2.97(2 \mathrm{H}), 3.25(1 \mathrm{H}), 4.42(2 \mathrm{H}), 7.64$ $8.56(5 \mathrm{H})$. Elemental analysis for $\mathrm{C}_{16} \mathrm{H}_{20} \mathrm{~N}_{2} \mathrm{O}_{3}$ : Calculated C (66.65\%), H (6.99\%), N (9.71\%), Found C (66.48\%), H (7.10\%), N (9.62\%).

\section{Results and Discussion}

Ethyl L-lysine dihydrochloride was prepared with the reaction of a mixture of $\mathrm{EtOH}$ and thionyl chloride with Llysine hydrochloride. L-lysine hydrochloride was added to the mixture dropwise at $-10^{\circ} \mathrm{C}$ and then refluxed for 6 hours. The dark solid was washed three times with diethyl ether to leave a bright white solid (87\%). FT-IR spectroscopy shows a strong and broad peak at $3350-2514 \mathrm{~cm}^{-1}$ corresponding to the Amonium $\mathrm{N}-\mathrm{H}$ stretchings and a strong peak at $1740 \mathrm{~cm}^{-1}$ corresponding to the $\mathrm{C}=\mathrm{O}$ stretchinng of ester

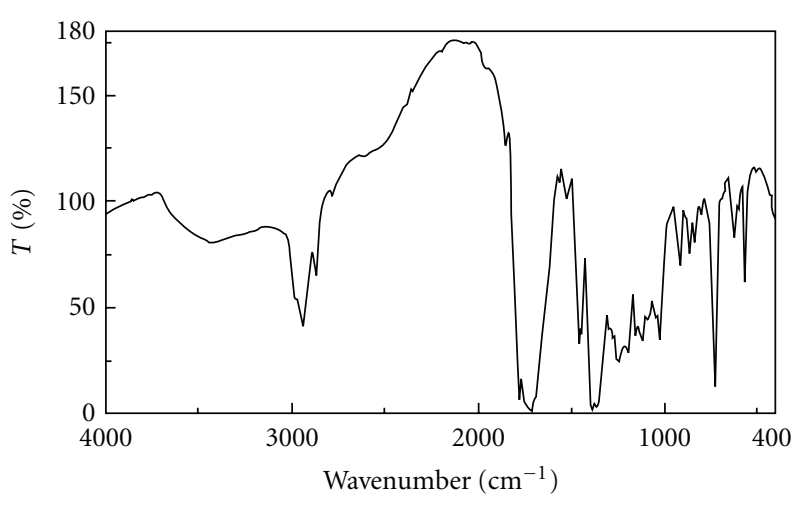

Figure 1: IR spectrum of $\mathbf{P I}_{1}$.

moiety. ${ }^{1} \mathrm{H}-\mathrm{NMR}\left(\mathrm{D}_{2} \mathrm{O}\right.$, ppm) spectroscopy shows the corresponding peaks such as $3.91(1 \mathrm{H})$ due to the chiral center and $1.07(3 \mathrm{H})$ and $2.78(2 \mathrm{H})$ peaks due to the ethyl moiety.

Solution polymerization in DMF in the presence of $\mathrm{Et}_{3} \mathrm{~N}$ was applied to prepare the polymers from ethyl L-lysine dihydrochloride and the other corresponding monomers (Schemes 1 and 2). PAs were prepared at r.t. but in preparing the PIs the mixture was refluxed to turn the amic acid 
<smiles>CCCCCCC(CC)n1c(=O)c2cc3c(=O)n(C)c(=O)c3cc2c1=O</smiles>

Head-to-tail regiorandomness of the polymer has not been represented for the sake of simplicity

(a)

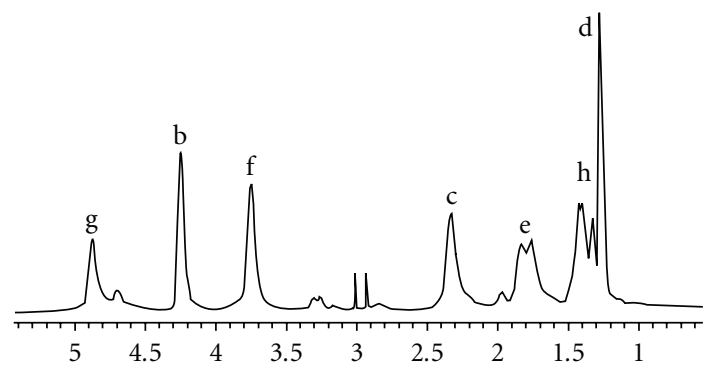

(b)

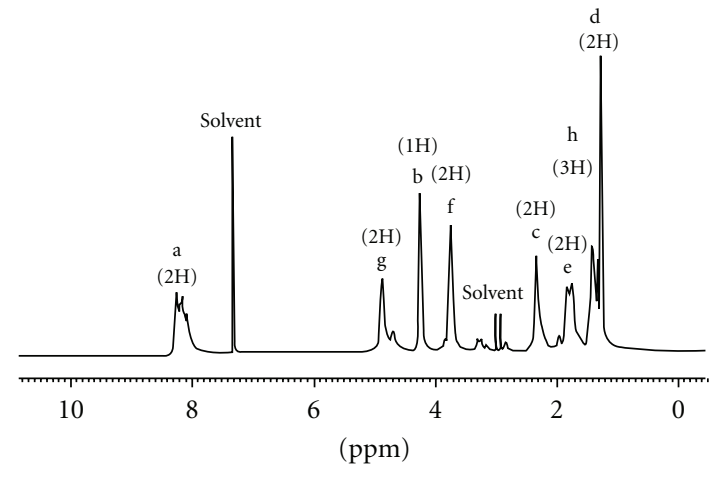

(c)

Figure 2: ${ }^{1} \mathrm{H}$ NMR spectrum of very probable atactic $\mathbf{P I}_{1}$.

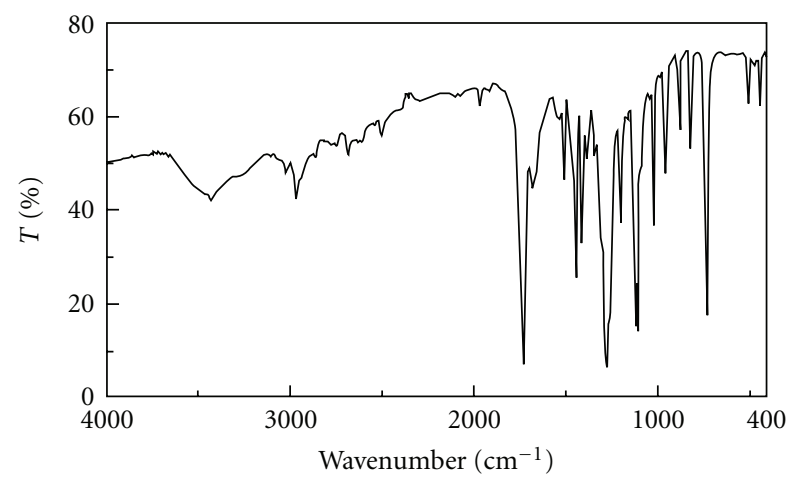

Figure 3: IR spectrum of $\mathbf{P A}_{4}$.

groups to imide. $\mathrm{Et}_{3} \mathrm{~N}$ was used to release the amino group of the L-lysine derivative and also to scavenge the released $\mathrm{HCl}$ in amidation. We also found that using an ionic liquid (1-methyl-3-propyl imidazolium bromide) as the solvent of polymerization can cause some difficulties in purification, so it is an unsuitable polymerization media.

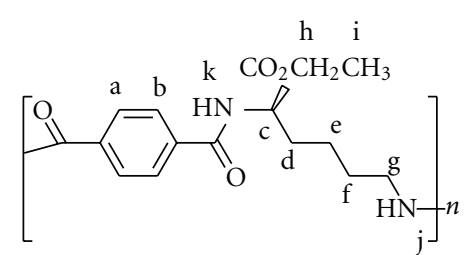

Head-to-tail regiorandomness of the polymer has not been represented for the sake of simplicity

(a)

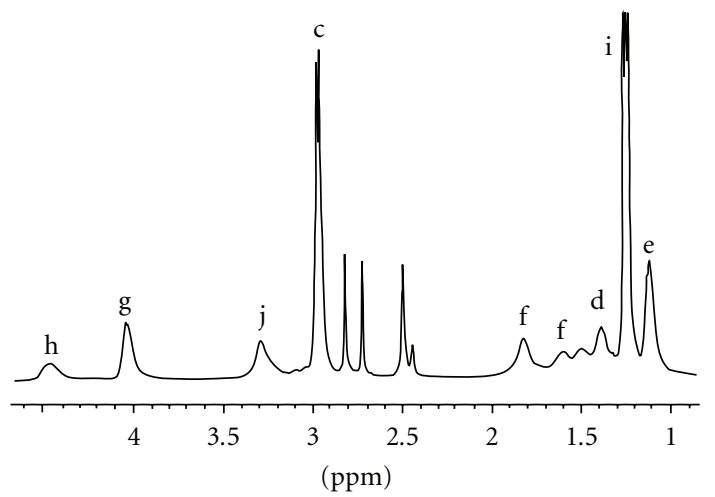

(b)

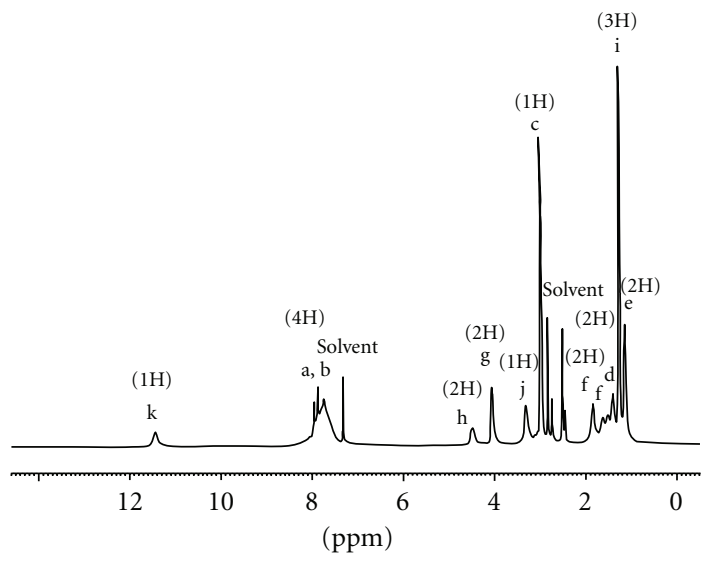

(c)

FIgURe 4: ${ }^{1} \mathrm{H}$ NMR spectrum of very probable atactic $\mathbf{P A}_{4}$.

All of the very probable atactic polymers were obtained from an inexpensive starting material in quantitative yields with moderate inherent viscosities $\left(0.15-0.42 \mathrm{dL} \mathrm{g}^{-1}\right)$ and optical rotation $\left(-28.12^{\circ}\right.$ to $\left.-48.56^{\circ}\right)$. As there is no obvious regioselectivity between alpha and epsilon amino groups of the lysine ester during the polymerisation step then random orientation of lysine moieties along the polymer backbone can be predicted and the concept of "tacticity" cannot be addressed in this research. Head-to-tail regiorandomness may likely affect some physical properties of the polymers such as crystallinity. The formation of PIs was confirmed by IR and ${ }^{1} \mathrm{H}$ NMR spectroscopy and elemental analysis. As an example, the IR of $\mathbf{P I}_{1}$ showed the $\mathrm{C}=\mathrm{O}$ asymmetric stretching of imide group, the $\mathrm{C}=\mathrm{O}$ symmetric stretching of imide and ester groups at $1774-1680 \mathrm{~cm}^{-1}, \mathrm{C}-\mathrm{N}$ stretching at around $1386 \mathrm{~cm}^{-1}$, and $\mathrm{C}-\mathrm{O}$ stretching at $1120 \mathrm{~cm}^{-1}$. 


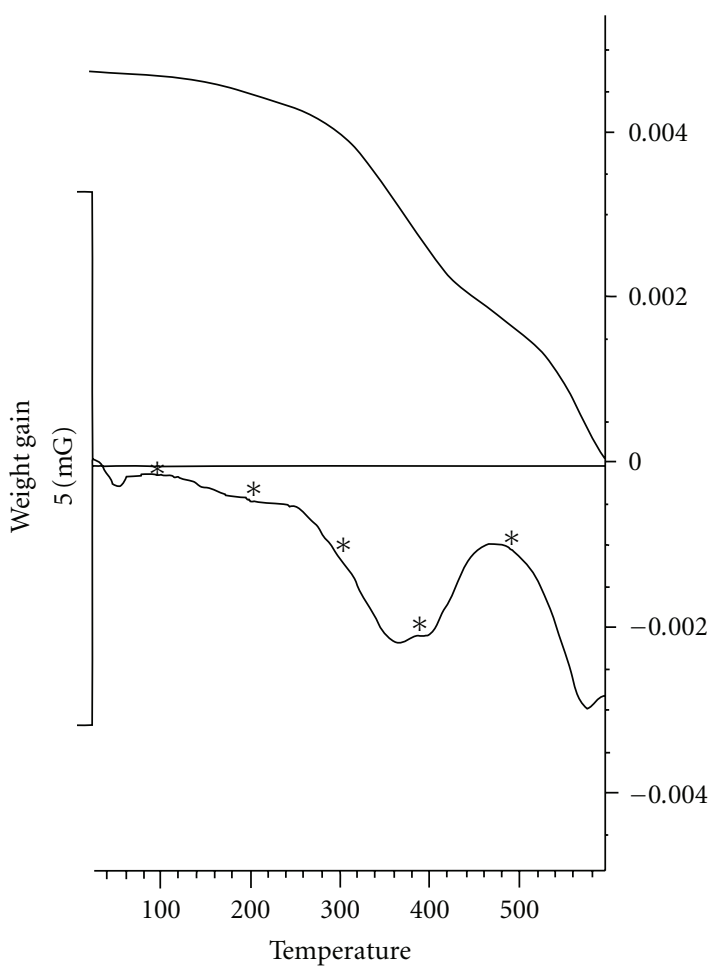

Figure 5: TGA/DTG spectrum of $\mathbf{P I}_{1}$.

All of these PIs exhibited strong absorption at around 1380 and $720 \mathrm{~cm}^{-1}$, which shows the presence of the heterocyclic imide groups (Figure 1). As an example the ${ }^{1} \mathrm{H}$ NMR spectrum of $\mathbf{P I}_{1}$ is presented in Figure 2 which shows peaks that confirmed its chemical structure $\left({ }^{1} \mathrm{H}\right.$ NMR (DMSO-d $\left.\mathrm{d}_{6}, \mathrm{ppm}\right): 1.26(2 \mathrm{H}), 1.41(3 \mathrm{H}), 1.76-1.83$ $(2 \mathrm{H}), 2.33(2 \mathrm{H}), 3.74(2 \mathrm{H}), 4.23(1 \mathrm{H}), 4.87(2 \mathrm{H}), 8.06-$ $8.29(2 \mathrm{H}))$. The formation of PAs was confirmed by IR and ${ }^{1} \mathrm{H}$ NMR spectroscopy and elemental analysis. As an example, the IR of $\mathbf{P A}_{4}$ showed the $\mathrm{N}-\mathrm{H}$ stretching of amide group at $3423 \mathrm{~cm}^{-1}$, the $\mathrm{C}=\mathrm{O}$ stretching of amide and ester and also the $\mathrm{N}-\mathrm{H}$ bending of amide groups at $1727-1615 \mathrm{~cm}^{-1}$ and the $\mathrm{C}-\mathrm{O}$ stretching at $1118 \mathrm{~cm}^{-1}$ (Figure 3). As an example the ${ }^{1} \mathrm{H}$ NMR spectrum of $\mathbf{P A}_{4}$ is presented which shows peaks that confirmed its chemical structure (Figure 4). The elemental analyses results are also in good agreement with calculated/expected percentages of carbon, hydrogen, and nitrogen contents in the polymerrepeating units. The color of these polymers was white. The resulting homogenous glassy compound films were isolated by adding methanol/ $\mathrm{H}_{2} \mathrm{O}(80: 20)$ and triturating, followed by filtration. It was washed several times with methanol and vacuum dried. Transparent, flexile, and tough films of these polymers were obtained which showed good mechanical strength of the films and consequently high molecular weight. Wide-angle X-ray diffraction patterns of $\mathbf{P I}_{1}$ in the region of $2 \theta=5-70^{\circ}$ at room temperature indicate 20$30 \%$ of crystallinity. TGA technique shows moderate to good thermal stability for these polymers (Table 1). For example the TGA/DTG spectrum of $\mathbf{P I}_{1}$ presents $T_{5} \%$ and $T_{10} \%$ at around $240^{\circ} \mathrm{C}$ and $310^{\circ} \mathrm{C}$, respectively. These polymers can
TABLE 1: Thermal behavior of polymers.

\begin{tabular}{lllc}
\hline Polymer & $\begin{array}{l}\text { Decomposition } \\
\text { temperature } \\
\left({ }^{\circ} \mathrm{C}\right) T_{5 \%}{ }^{\mathrm{a}}\end{array}$ & $\begin{array}{l}\text { Decomposition } \\
\text { temperature } \\
\left({ }^{\circ} \mathrm{C}\right) T_{10 \%}{ }^{\mathrm{b}}\end{array}$ & Char yield $(\%)^{\mathrm{c}}$ \\
\hline $\mathbf{P I}_{1}$ & 240 & 310 & 5.2 \\
$\mathbf{P I}_{2}$ & 225 & 300 & 6.4 \\
$\mathbf{P I}_{3}$ & 230 & 335 & 7.0 \\
$\mathbf{P A}_{4}$ & 280 & 350 & 3.4 \\
$\mathbf{P A}_{5}$ & 265 & 345 & 2.5 \\
\hline
\end{tabular}

${ }^{\mathrm{a}}$ Temperature at which $5 \%$ weight loss was recorded by TGA at a heating rate of $10^{\circ} \mathrm{C} / \mathrm{min}$ under air atmosphere. ${ }^{\mathrm{b}}$ Temperature at which $10 \%$ weight loss was recorded by TGA at a heating rate of $10^{\circ} \mathrm{C} / \mathrm{min}$ under air atmosphere. ${ }^{c}$ Percentage weight of material left after TGA analysis at maximum temperature $600^{\circ} \mathrm{C}$ under air atmosphere

TABLE 2: Solubility of polymers ${ }^{\mathrm{a}}$.

\begin{tabular}{lccccc}
\hline Solvents & $\mathbf{P I}_{1}$ & $\mathbf{P I}_{2}$ & $\mathbf{P I}_{3}$ & $\mathbf{P A}_{4}$ & $\mathbf{P A}_{5}$ \\
\hline $\mathrm{NMP}$ & + & + & + & + & + \\
DMSO & + & + & + & + & + \\
DMAc & + & + & + & + & + \\
$\mathrm{DMF}$ & + & + & + & + & + \\
$\mathrm{H}_{2} \mathrm{SO}_{4}$ & + & + & + & + & + \\
$\mathrm{CH}_{2} \mathrm{Cl}_{2}$ & - & - & - & - & - \\
$\mathrm{CHCl}_{3}$ & - & - & - & - & - \\
$\mathrm{EtOH}$ & - & - & - & - & - \\
$\mathrm{MeOH}$ & - & - & - & - & - \\
$\mathrm{H}_{2} \mathrm{O}$ & - & - & - & - & - \\
\hline
\end{tabular}

a Concentration: $5 \mathrm{mg} \mathrm{mL}^{-1}$ : +, soluble at room temperature; -, insoluble.

be partially hydrolyzed to present the pendent carboxylic acid groups (ion-exchangeable polymers). $\mathbf{P A}_{5}$ can potentially be photolabile and be used to prepare an affinity column. It is because of the presence of benzophenone moiety. One of the major objectives of this work is to study the solubility and the versatility of these polymers by incorporating the soft segment in the polymer backbone. The solubility of these polymers was tested qualitatively in various solvents and the results are summarized in Table 2 .

\section{Conclusions}

Five new chiral polyamides and polyimides incorporating ethyl L-lysine ester have been synthesized from an inexpensive starting material by usual solution polycondensation method. These polymers are very soluble, optically active, potentially ion exchangeable and semicrystalline. The resulting polymers are identified spectroscopic methods such as FT-IR, UV-Vis and ${ }^{1} \mathrm{H}$ NMR spectroscopy and elemental analysis. The polymers are characterized by yield of reaction, inherent viscosity, WAX diffraction, and specific rotation.

\section{Acknowledgment}

The authors gratefully acknowledge the funding support received for this paper from Firouzabad Islamic Azad University. 


\section{References}

[1] K. L. Mittal, Polyimides: Synthesis, Characterization and Application, Plenum Press, New York, NY, USA, 1984.

[2] M. J. M. Abade, Ed., Polyimides and other High-Temperature Polymers, Elsevier, New York, NY, USA, 1991.

[3] A. Banihashemi and A. Abdolmaleki, "Novel aromatic polyimides derived from benzofuro[2,3-b]benzofuran-2,3,8,9tetracarboxylic dianhydride (BBTDA)," European Polymer Journal, vol. 40, no. 8, pp. 1629-1635, 2004.

[4] M. K. Ghosh and K. L. Mittal, Eds., Polyimide: Fundamentals and applications, Marcel Dekker, New York, NY, USA, 1996.

[5] D. Wilson, Stenzenberger, and Hergenrother, Polyimides, Blackie, Glasgow, UK, 1990.

[6] S. Tamai, A. Yamaguchi, and M. Ohta, "Melt processible polyimides and their chemical structures," Polymer, vol. 37, no. 16, pp. 3683-3692, 1996.

[7] S.-H. Hsiao and C.-T. Li, "Synthesis and characterization of new adamantane-based polyimides," Macromolecules, vol. 31, no. 21, pp. 7213-7217, 1998.

[8] W. T. Müller and H. Ringsdorf, "Acetylene-substituted aromatic polyamides: curable systems," Macromolecules, vol. 23, no. 11, pp. 2825-2829, 1990.

[9] F. Li, J. J. Ge, P. S. Honigfort et al., "Dianhydride architectural effects on the relaxation behaviors and thermal and optical properties of organo-soluble aromatic polyimide films," Polymer, vol. 40, no. 18, pp. 4987-5002, 1999.

[10] D. S. Reddy, C.-H. Chou, C.-F. Shu, and G.-H. Lee, "Synthesis and characterization of soluble poly(ether imide)s based on 2,2' -bis(4-aminophenoxy)-9,9' -spirobifluorene," Polymer, vol. 44, no. 3, pp. 557-563, 2002.

[11] N. R. Legge, G. Holden, and H. E. Schroeder, Thermoplastic Elastomers, Hanser, New York, NY, USA, 1987.

[12] A. Noshay and I. E. McGrath, Block Copolymers, Academic Press, New York, NY, USA, 1977.

[13] A. R. Hajipour, S. Zahmatkesh, A. Zarei, L. Khazdooz, and A. E. Ruoho, "Synthesis and characterization of novel optically active poly(amide-imide) s via direct amidation," European Polymer Journal, vol. 41, no. 10, pp. 2290-2296, 2005.

[14] A. Akelah and D. C. Sherrington, "Application of functionalized polymers in organic synthesis," Chemical Reviews, vol. 81, no. 6, pp. 557-587, 1981.

[15] M. Aglietto, E. Chiellini, S. D’Antone, G. Ruggeri, and R. Solaro, "CHIRAL POLYMER CATALYSTS IN PREPARATIVE ORGANIC CHEMISTRY: A CRITICAL OVERVIEW,” Pure and Applied Chemistry, vol. 60, no. 3, pp. 415-430, 1987.

[16] H. Yuki, Y. Okamoto, and I. Okamoto, "Resolution of racemic compounds by optically active poly(triphenylmethyl methacrylate) [13]," Journal of the American Chemical Society, vol. 102, no. 20, pp. 6356-6358, 1980.

[17] Y. Okamoto and E. Yashima, "Polysaccharide derivatives for chromatographic separation of enantiomers," Angewandte Chemie International Edition, vol. 37, no. 8, pp. 1020-1043, 1998.

[18] K. Soai and S. Niwa, "Enantioselective addition of organozinc reagents to aldehydes," Chemical Reviews, vol. 92, no. 5, pp. 833-856, 1992.

[19] G. Wulff, "Main-chain chirality and optical activity in polymers consisting of C-C chains," Angewandte Chemie International Edition, vol. 28, no. 1, pp. 21-37, 1989.

[20] M. Fontanille and M. Guyot, Eds., Recent Advances in Synthetic and Mechanistic Aspects of Polymerization, Kluwer Academic Publishers, Dordrecht, The Netherlands, 1987.
[21] A. C. Birchall, S. M. Bush, and M. North, "Copolymerization of peptide derived monomers and methyl methacrylate," Polymer, vol. 42, no. 2, pp. 375-389, 2001.

[22] S. E. Mallakpour, A.-R. Hajipour, and R. Vahabi, "Synthesis and characterization of novel poly(amide imide)s based on bis(p-amidobenzoic acid)-N-trimellitylimido-L-leucine," Journal of Applied Polymer Science, vol. 84, no. 1, pp. 35-43, 2002.

[23] S. Mallakpour and M. Kolahdoozan, "Room temperature ionic liquids as replacements for organic solvents: direct preparation of wholly aromatic polyamides containing phthalimide and S-valine moieties," Polymer Journal, vol. 40, no. 6, pp. 513-519, 2008.

[24] S. E. Mallakpour, A.-R. Hajipour, A.-R. Mahdavian, and F. Rafiemanzelat, "Highly diastereoselective synthesis of novel polymers via tandem Diels-Alder-ene reactions," Polymer International, vol. 48, no. 2, pp. 109-116, 1999.

[25] A. R. Hajipour, P. Roosta, S. Zahmatkesh, and A. E. Ruoho, "Synthesis and characterization of novel optically active poly(ester-imide-imine)s," E-Polymers, pp. 1-11, 2009.

[26] J. J. Bou and S. Muñoz-Guerra, "Synthesis and characterization of a polytartaramide based on 1-lysine," Polymer, vol. 36, no. 1, pp. 181-186, 1995.

[27] M. A. Majó, A. Alla, J. J. Bou, C. Herranz, and S. Muñoz-Guerra, "Synthesis and characterization of polyamides obtained from tartaric acid and L-lysine," European Polymer Journal, vol. 40, no. 12, pp. 2699-2708, 2004.

[28] L. W. Guo, A. R. Hajipour, M. L. Gavala, J. E. Grant, and A. E. Ruoho, "Crosslinking of full-length reversible PDE gamma benzophenone photoprobes to G alpha t-GTP gamma S," FASEB Journal, vol. 18, p. A587, 2004.

[29] J. J. Bou, A. Rodriguez-Galan, and S. Munoz-Guerra, "Biodegradable polyamides from tartaric acid," in The Polymeric Materials Encyclopedia, E. Salamone, Ed., vol. 1, pp. 561569, CRC Press, Boca Raton, Fla, USA, 1996. 

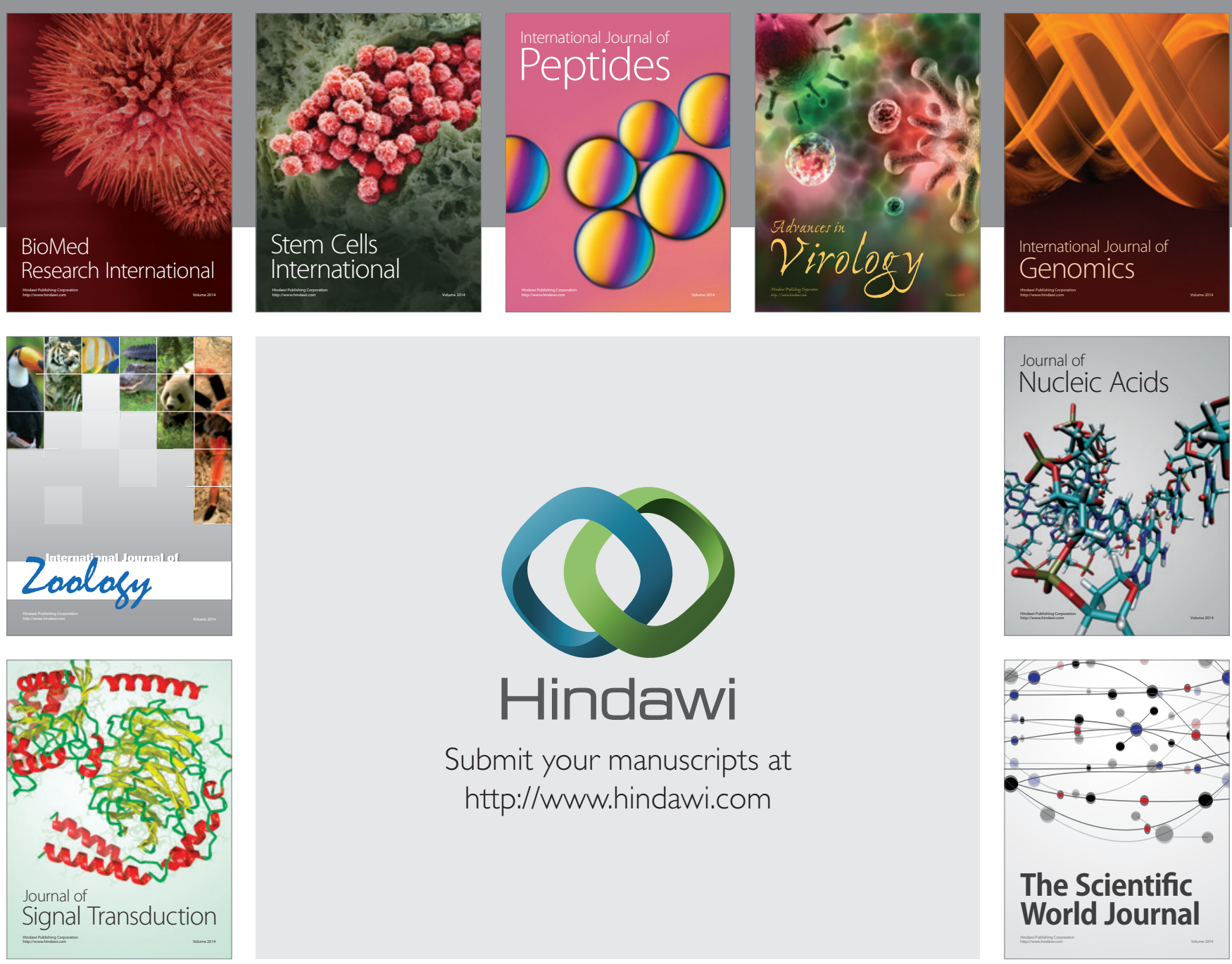

Submit your manuscripts at

http://www.hindawi.com
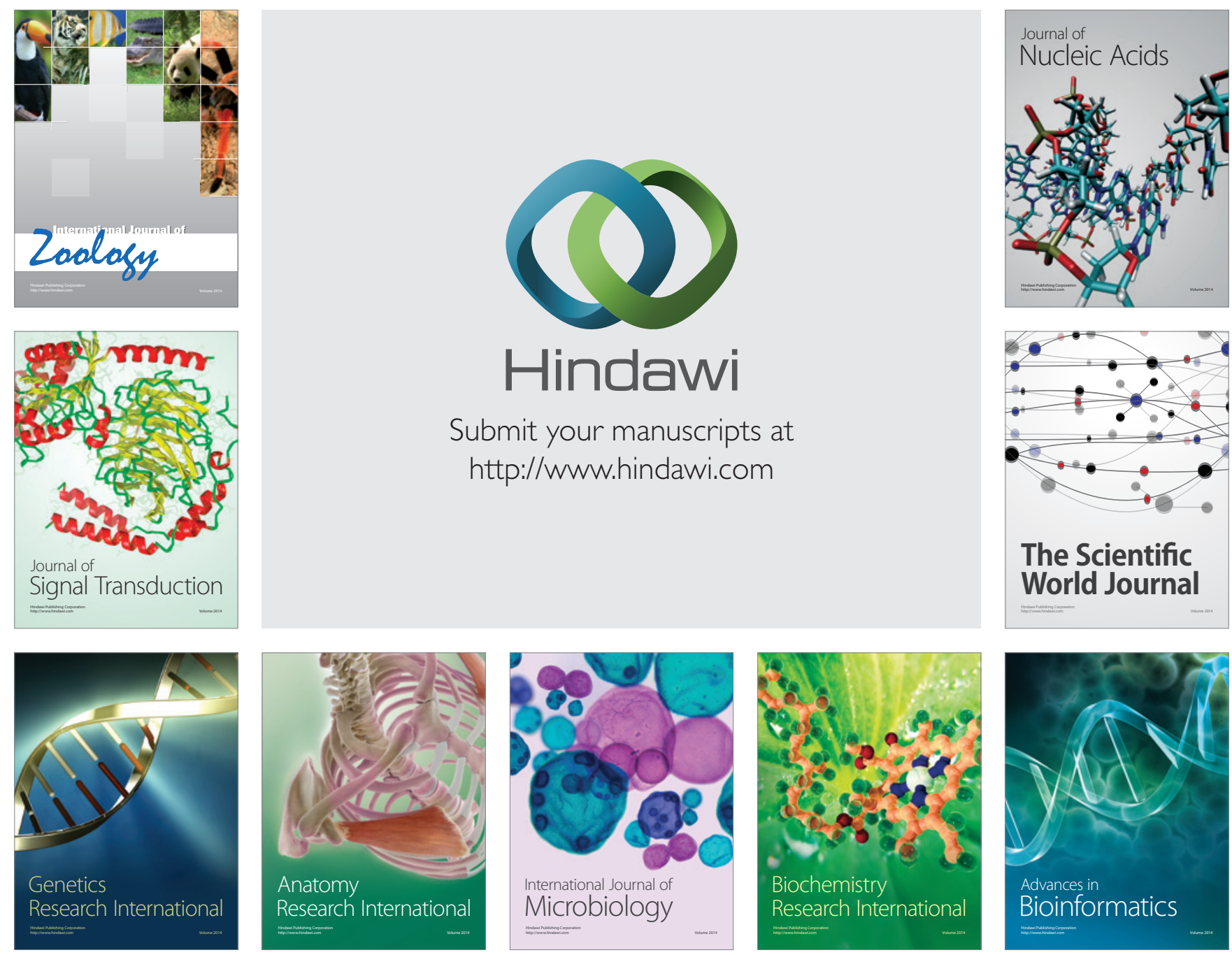

The Scientific World Journal
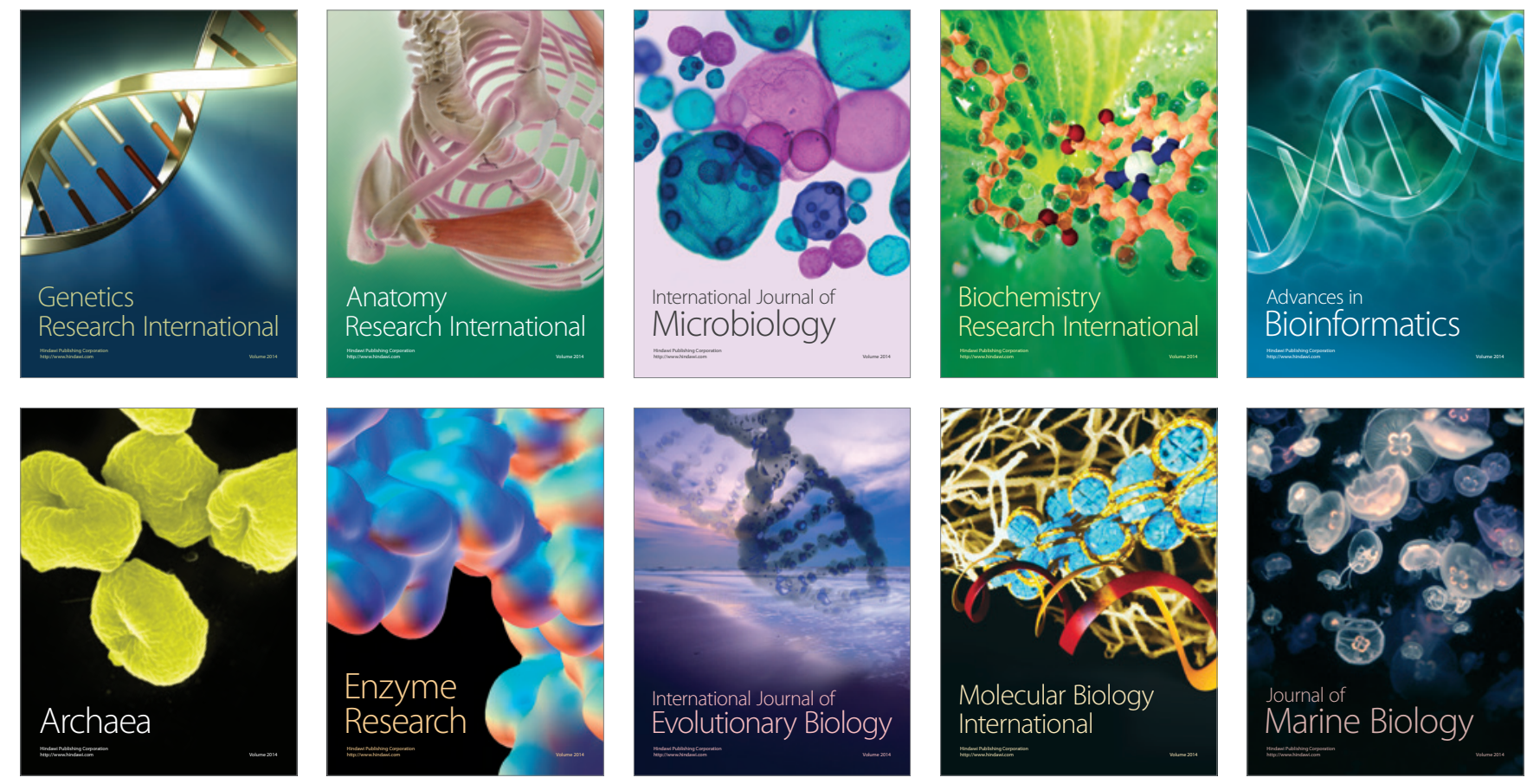